\title{
Vitamin A decreases pre-receptor amplification of glucocorticoids in obesity: study on the effect of vitamin A on 11 beta-hydroxysteroid dehydrogenase type 1 activity in liver and visceral fat of WNIN/Ob obese rats
}

\author{
Vara Prasad SS Sakamuri', Prashanth Ananthathmakula', Giridharan Nappan Veettil ${ }^{2}$ and
}

Vajreswari Ayyalasomayajula ${ }^{1 *}$

\begin{abstract}
Background: $11 \beta$-hydroxysteroid dehydrogenase type 1 (11 $\beta$-HSD1) catalyzes the conversion of inactive glucocorticoids to active glucocorticoids and its inhibition ameliorates obesity and metabolic syndrome. So far, no studies have reported the effect of dietary vitamin A on 113-HSD1 activity in visceral fat and liver under normal and obese conditions. Here, we studied the effect of chronic feeding of vitamin A-enriched diet (129 mg/kg diet) on $11 \beta$-HSD1 activity in liver and visceral fat of WNIN/Ob lean and obese rats.

Methods: Male, 5-month-old, lean and obese rats of WNIN/Ob strain ( $n=16$ for each phenotype) were divided into two subgroups consisting of 8 rats of each phenotype. Control groups received stock diet containing $2.6 \mathrm{mg}$ vitamin A/kg diet, where as experimental groups received diet containing $129 \mathrm{mg}$ vitamin A/Kg diet for 20 weeks. Food and water were provided ad libitum. At the end of the experiment, tissues were collected and 11 $\beta$-HSD1 activity was assayed in liver and visceral fat.
\end{abstract}

Results: Vitamin A supplementation significantly decreased body weight, visceral fat mass and 11ß-HSD1 activity in visceral fat of WNIN/Ob obese rats. Hepatic $11 \beta-H S D 1$ activity and gene expression were significantly reduced by vitamin A supplementation in both the phenotypes. CCAAT/enhancer binding protein $\alpha$ (C/EBP $\alpha$ ), the main transcription factor essential for the expression of $11 \beta-H S D 1$, decreased in liver of vitamin A fed-obese rats, but not in lean rats. Liver $\times$ receptor $\alpha(L X R \alpha)$, a nuclear transcription factor which is known to downregulate $11 \beta-H S D 1$ gene expression was significantly increased by vitamin A supplementation in both the phenotypes.

Conclusions: This study suggests that chronic consumption of vitamin A-enriched diet decreases 11 $\beta$-HSD1 activity in liver and visceral fat of WNIN/Ob obese rats. Decreased 11ß-HSD1 activity by vitamin A may result in decreased levels of active glucocorticoids in adipose tissue and possibly contribute to visceral fat loss in these obese rats. Studying the role of various nutrients on the regulation of 11ß-HSD1 activity and expression will help in the evolving of dietary approaches to treat obesity and insulin resistance.

\footnotetext{
* Correspondence: vaj_lipidresearch@yahoo.com

'Department of Biochemistry, National Institute of Nutrition, Indian Council of Medical Research, Jamai Osmania PO, Hyderabad-500 604, Andhra

Pradesh, India

Full list of author information is available at the end of the article
} 


\section{Background}

$11 \beta$-hydroxysteroid dehydrogenase type 1 (11ß-HSD1) modulates the local glucocorticoid metabolism by catalyzing the conversion of inactive glucocorticoids (cortisone in humans and 11-dehydrocorticosterone in rodents) to active glucocorticoids (cortisol in humans and corticosterone in rodents). Recent studies have shown that, $11 \beta$-HSD1 plays an important role in the development of obesity $[1,2]$. Transgenic mice overexpressing $11 \beta-H S D 1$ in adipose tissue developed visceral obesity [3], where as 11 $\beta$-HSD1 knock-out mice displayed resistance to diet-induced obesity [4]. Administration of carbenoxolone, a non-selective $11 \beta-$ HSD1 inhibitor, has been shown to decrease obesity in animal models [5]. 11 $\beta$-HSD1 gene expression is directly regulated by CCAAT/enhancer-binding protein $\alpha(\mathrm{C} / \mathrm{EBP} \alpha)$ [6], where as its expression is down regulated by Liver $x$ receptor $\alpha(\mathrm{LXR} \alpha)$ [7].

Studies on rodent models of obesity provided valuable information regarding the molecular mechanisms involved in the development of obesity and its associated complications. WNIN/Ob obese rat colony was established by selective breeding of spontaneously mutated obese rat, identified in 80 year-old inbred wistar rat colony at National Institute of Nutrition (NIN, Hyderabad, India) [8]. The rat colony shows three phenotypes (also genotypes), lean $(+/+)$, carrier $(+/-)$ and obese (-/-). WNIN/Ob lean and carrier rats are fertile, where as obese rats are sterile. The obese rat colony is maintained by crossing between carrier rats, which results in genotypic ratio (and also phenotypic ratio) of 1:2:1 (lean: carrier: obese) indicating the autosomal codominant nature of the mutation. WNIN/Ob obese rats develop severe obesity with onset around 35 days of age. These rats are hyperphagic, hyperinsulinemic, hyperleptinemic and dyslipidemic [8]. Preliminary studies on WNIN/Ob obese rats have revealed no molecular defects in leptin and leptin receptor. Recent studies have located the mutation on $5^{\text {th }}$ chromosome [unpublished data] and further investigations are underway to identify the molecular mutation leading to the development of obesity in these obese rats.

Diet plays an important role in the development, progression and amelioration of chronic diseases like obesity and diabetes. Studies on the effect of nutrients on $11 \beta$-HSD1 activity and expression will greatly help in understanding the mechanisms underlying the development of obesity and its associated metabolic disorders. Vitamin A, an important micronutrient has divergent biological functions in animal physiology. Vitamin Aenriched diet has been shown to decrease adiposity and alter adipose tissue gene expression in rats [9]. Our previous studies on supplementation of high but non-toxic dose of vitamin A to obese rats of WNIN/Ob strain have shown to decrease adiposity $[10,11]$. So far, no studies have addressed the role of vitamin $\mathrm{A}$ in the regulation of $11 \beta$-HSD 1 activity in normal and obese conditions. As vitamin A is known to alter the expression of genes regulated by $\mathrm{C} / \mathrm{EBP} \alpha$ [12], here, we hypothesize that supra-physiological (high but nontoxic) dose of vitamin A modulates 11 $\beta$-HSD1 activity in adipose tissue under normal and obese conditions. To test our hypothesis, we studied the activity of $11 \beta$ HSD1 in visceral fat and liver of WNIN/Ob lean and obese rats, after chronic challenging with vitamin Aenriched diet (129 mg/Kg diet) for 20 weeks.

\section{Methods}

\section{Animal experiment}

Male, 5-month-old WNIN/Ob lean and obese rats $(\mathrm{n}=$ 16 for each phenotype) were obtained from the National Centre for Laboratory animal sciences, and divided into two groups A and B based on phenotype. Each group was further divided into two subgroups (AI, AII \& BI, BII) consisting of 8 rats from each phenotype. The animals were housed individually in a temperature $\left(22 \pm 2^{\circ}\right.$ C) and light controlled (12 h cycle) animal facility. Animals of AI and BI subgroups were fed on stock diet containing $2.6 \mathrm{mg}$ of vitamin $\mathrm{A} / \mathrm{Kg}$ diet (Recommended daily allowance), while those in AII and BII subgroups were fed on experimental diet containing $129 \mathrm{mg}$ of vitamin $\mathrm{A} / \mathrm{Kg}$ diet (as retinyl palmitate- a generous gift from Nicholas Piramal India Limited). Animals were maintained on their respective diets for a period of 20 weeks. Food and water were provided ad libitum. Daily food intake and weekly body weights were recorded. The study was approved by Institutional Animal Ethical Committee (IAEC). At the end of the experiment, blood was collected after overnight fast, between 9.00 AM and 11.00 AM. Animals were sacrificed and tissues were collected and stored at $-80^{\circ} \mathrm{C}$ for further analysis.

\section{Plasma and tissue parameters}

Plasma corticosterone levels were measured by radioimmunoassay (RIA) kit method (Siemens, Los Angeles, USA). Plasma, liver and visceral fat retinol levels were measured by methods described previously [10].

\section{Measurement of $11 \beta-H S D 1$ activity}

$11 \beta-H S D 1$ functions as a reductase in vivo, reactivating corticosterone from inactive 11-dehydrocorticosterone. However, in tissue homogenates, dehydrogenase activity predominates, therefore, $11 \beta$-HSD1 activity was measured by the conversion of corticosterone to 11-dehydrocorticosterone. We studied $11 \beta-H S D 1$ activity in visceral fat by taking omental adipose tissue, as it is known to exhibit 
higher enzyme activity. Post-nuclear fractions from liver and visceral fat were prepared by centrifuging tissue homogenate at $1000 \mathrm{~g}$ for $20 \mathrm{~min}$. $11 \beta$-HSD1 activity was measured in post nuclear fractions of liver and visceral fat by incubating in duplicate at $37^{\circ} \mathrm{C}$ in Krebs-Ringer buffer containing glucose $(0.2 \%)$, NADP $(1 \mathrm{mM})$ and $1,2,6$, 7$\left[{ }^{3} \mathrm{H}_{4}\right]$ corticosterone (50 nM). Conditions were optimized for both tissues to ensure first order kinetics, by adjusting protein concentrations for liver $(40 \mu \mathrm{g} / \mathrm{ml})$ and omental adipose tissue $(1 \mathrm{mg} / \mathrm{ml})$. After incubation (40 $\mathrm{min}$ for liver and $6 \mathrm{~h}$ for omental adipose tissue), steroids were extracted with ethyl acetate, the organic phase was evaporated under nitrogen, and extracts resuspended in mobile phase (50\% water, $30 \%$ acetonitrile and $20 \%$ methanol). Steroids were separated by HPLC using reverse phase C18 column and fractions containing corticosterone and 11dehydrocorticosterone were collected and radioactivity was counted in liquid scintillation counter (PerkinElmer, USA).

\section{Measurement of glycerol-3-phosphate dehydrogenase (GPDH) activity}

$50 \mathrm{mg}$ of liver tissue was homogenized in $10 \mathrm{mM}$ TrisHcl buffer (pH-7.4) containing $1 \mathrm{mM} 2$-mercaptoethanol and 5\% protease inhibitor cocktail (Sigma, USA). Homogenate was centrifuged at $10,000 \mathrm{~g}$ for 20 minutes at $4^{\circ} \mathrm{C}$ and the supernatant was used for the estimation of cytosolic GPDH activity. GPDH activity was measured by the method of White and Kaplan and expressed as nanomoles of NADH utilized $/ \mathrm{min} / \mathrm{mg}$ of protein (13).

\section{Measurement of relative gene expression by semi- quantitative Reverse Transcription PCR}

As lean rats have limited omental adipose tissue, which we utilized for the enzyme assay, we carried out gene expression work only in liver but not in adipose tissue. Total cellular RNA from liver was extracted using the method of Chomczynski and Sacchi [14]. The integrity of RNA was checked using $1 \%$ agarose gels stained with ethidium bromide. Total RNA was quantified by spectrophotometric absorption at $260 \mathrm{~nm} .1 .0 \mu \mathrm{g}$ of RNA was used for synthesizing first strand cDNA. The reverse transcription (RT) reaction was carried out by incubating RNA with $0.5 \mu$ g oligo dT primer (Sigma, USA) and 100 units of Molony murine leukemia virus reverse transcriptase (Finnzymes, Espoo, Finland) at $37^{\circ}$ $\mathrm{C}$ for $60 \mathrm{~min}$. Total reaction volume used for RT was $20 \mu \mathrm{L}$. An aliquot of cDNA was amplified in a $20 \mu \mathrm{L}$ reaction mixture. PCR conditions are given below: denaturation at $94^{\circ} \mathrm{C}$ for 1 minute, annealing at $60-64^{\circ} \mathrm{C}$ for $45 \mathrm{sec}$ and polymerization for $70{ }^{\circ} \mathrm{C}$ for $1 \mathrm{~min}$ with DyNAzyme II DNA polymerase (Finnzymes, Espoo, Finland). A final extension was carried out at $70{ }^{\circ} \mathrm{C}$ for 7 min. The amount of RNA and the annealing temperature for different genes were standardized for linearity. Sequences of primers used for amplification are $11 \beta$ HSD1: forward primer-5'-GAGGAAGGGCTCCAG-3' and reverse primer-5'-GAGCAAACTTGCTTGCA3'(NM_017080), LXR $\alpha$ : forward primer-5'-GCCCCATGGACACCTA-3' and reverse primer-5'-TGAGGGTCG GGTGCAA-3' (NM_031627), C/EBP $\alpha$ : forward primer5'-GAGCCGAGATAAAGCCAA-3' and reverse primer 5'-CTTTCAGGCGACACCA-3' (NM_012524), $\beta$-actin: forward primer-5' - ACCAACTGGGACGACATGGA-3' and reverse primer-5' - TCTCAAACATGATCTGGG TCA-3' (NM_031144). $\beta$-actin mRNA was amplified as an internal control. Number of amplification cycles for each gene was standardized so that amplification will be in the logarithmic phase. After amplification, $8 \mu \mathrm{L}$ of reaction mixture were electrophoresed on agarose gel (2\%) in Tris-acetate EDTA buffer ( $\mathrm{pH}$ 8.2). The ethidium bromide stained bands were visualized by UVtransilluminator and analyzed densitometrically using Quantity One software (Bio-Rad, version 4.4.0).

\section{Immunoblotting}

Nuclear protein was extracted from liver as described previously $[15,16]$. Protein content was estimated by Bradford method. Proteins were separated by $10 \%$ SDSPAGE gel and probed by specific antibodies raised against C/EBP $\alpha$ and LXR $\alpha$ (Santa Cruz Biotechnology, Inc., and Santa Cruz, CA). Equal loading of protein and transfer were ensured by staining membranes with Ponseau S. Bands were scanned using GS 710 densitometer (Biorad, CA, USA) and band densities were analyzed by Quantity one software (Biorad, version 4.4.0).

\section{Statistics}

Data were analyzed by one way ANOVA by using least significant difference (LSD) post hoc test. Data are presented as mean \pm S.E. Statistical significance was taken at $\mathrm{P}<0.05$ level (two tailed).

\section{Results}

Effect of vitamin A supplementation on physical and biochemical parameters

Vitamin A supplementation significantly reduced body weight, body weight gain and visceral fat mass in obese rats compared to stock diet-fed obese rats (Table 1). Vitamin A supplementation did not alter the visceral fat mass or body weight in lean rats as compared with their stock-diet fed counterparts (Table 1). Food intake was not affected by vitamin A supplementation in both the phenotypes as compared with their respective control groups (Table 1). Consumption of vitamin A-enriched diet for 20 weeks significantly increased retinol levels in liver and visceral fat of lean and obese rats as compared 
Table 1 Effect of vitamin A supplementation on food intake and physical parameters in WNIN/Ob lean and obese rats

\begin{tabular}{|c|c|c|c|c|}
\hline & Al & All & $\mathrm{BI}$ & BII \\
\hline $\begin{array}{l}\text { Pre-treatment body } \\
\text { weight }(\mathrm{g})\end{array}$ & $375 \pm 16$ & $362 \pm 25$ & $628 \pm 38$ & $590 \pm 11$ \\
\hline $\begin{array}{l}\text { Post-treatment body } \\
\text { weight }(\mathrm{g})\end{array}$ & $406 \pm 23$ & $452 \pm 15$ & $916 \pm 48$ & $778 \pm 19^{*}$ \\
\hline Body weight (g) & $91 \pm 20$ & $89 \pm 14$ & $285 \pm 19$ & $188 \pm 14 \#$ \\
\hline Daily food intake (g) & $18 \pm 0.6$ & $18 \pm 0.8$ & $26 \pm 1.4$ & $26 \pm 0.9$ \\
\hline $\begin{array}{l}\text { Visceral fat ( } \mathrm{g} / 100 \mathrm{~g} \\
\text { body.wt) }\end{array}$ & $2.3 \pm 0.4$ & $2.5 \pm 0.4$ & $10.5 \pm 0.7$ & $7.0 \pm 0.5 \#$ \\
\hline
\end{tabular}

Values are mean \pm S.E of 8 rats. Values with ${ }^{\#}$ and ${ }^{*}$ mark are significant at $P$ $<0.01$ and $<0.05$ level respectively (by one-way ANOVA). Comparisons were made between normal and high vitamin A-fed groups of each phenotype (Al-Lean: $2.6 \mathrm{mg}$ vitamin A/Kg diet, All-Lean: $129 \mathrm{mg}$ vitamin A/Kg diet, BI-Obese: $2.6 \mathrm{mg}$ vitamin A/kg diet and Bll-Obese: $129 \mathrm{mg}$ vitamin A/kg diet)

with their respective stock-diet fed rats (Table 2). Plasma corticosterone levels were not altered by vitamin A supplementation in both the phenotypes (Table 2).

Effect of vitamin A supplementation on $11 \beta$-HSD1 activity in visceral fat

Vitamin A supplementation significantly decreased $11 \beta$ HSD1 activity in visceral fat of obese rats as compared to stock diet-fed obese rats (Figure 1). In contrast to the observation in obese rats, vitamin A supplementation significantly increased $11 \beta$-HSD1 activity in visceral fat of lean rats as compared with their stock diet-fed lean counterparts (Figure 1).

Effect of vitamin A supplementation on hepatic 11 $\beta$-HSD1 activity and expression

Vitamin A supplementation significantly decreased $11 \beta$ HSD1 activity in the liver of lean and obese rats as against their stock diet-fed lean and obese counterparts (Figure 2). In line with the decreased enzyme activity, $11 \beta$-HSD1 mRNA levels were significantly lower in high vitamin A-fed lean and obese rats as compared with their stock diet-fed lean and obese counterparts (Figure 2).

Table 2 Effect of vitamin A supplementation on biochemical parameters in WNIN/Ob lean and obese rats

\begin{tabular}{lllll}
\hline & Al & All & BI & BII \\
\hline $\begin{array}{l}\text { Plasma corticosterone } \\
\text { (ng/mL) }\end{array}$ & $227 \pm 50$ & $170 \pm 15$ & $256 \pm 27$ & $287 \pm 34$ \\
\hline Plasma retinol $(\mu \mathrm{g} / \mathrm{dL})$ & $28 \pm 0.5$ & $28 \pm 0.5$ & $40 \pm 0.6$ & $43 \pm 2.0$ \\
\hline $\begin{array}{l}\text { Liver total retinol } \\
\text { (mg/g tissue) }\end{array}$ & $0.9 \pm 0.1$ & $9.8 \pm 0.4^{\# \#}$ & $0.4 \pm 0.02$ & $8.1 \pm 0.3^{\# \#}$ \\
\hline $\begin{array}{l}\text { Visceral fat retinol } \\
\text { ( } \mathrm{g} / \mathrm{g} \text { tissue) }\end{array}$ & $4.0 \pm 1.2$ & $41 \pm 2.7^{\# \#}$ & $2.0 \pm 0.1$ & $4.8 \pm 2.0^{\# \#}$ \\
\hline
\end{tabular}

Values are means \pm S.E of 8 rats. Mean values with ${ }^{\# \#}$ mark are significant at $P$ $<0.001$ level (by one-way ANOVA). Comparisons were made between normal and high vitamin A-fed groups of each phenotype (Al-Lean: $2.6 \mathrm{mg}$ vitamin $\mathrm{A} / \mathrm{kg}$ diet, All-Lean: $129 \mathrm{mg}$ vitamin A/kg diet, Bl-Obese: $2.6 \mathrm{mg}$ vitamin A/kg diet and Bll-Obese: $129 \mathrm{mg}$ vitamin A/kg diet).

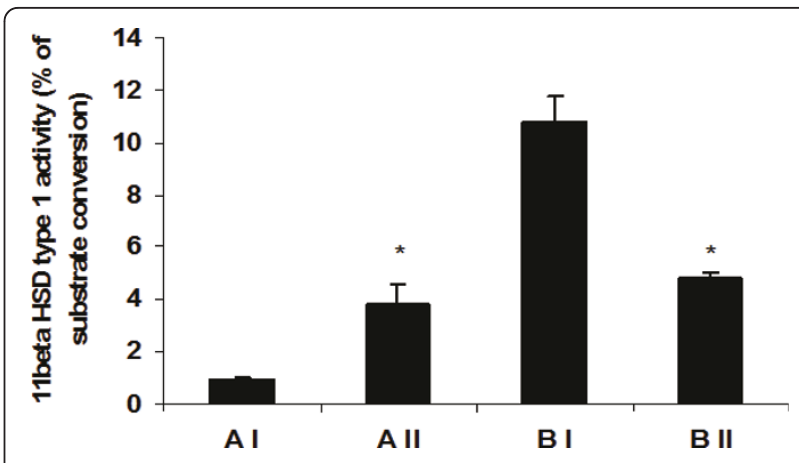

Figure 1 Effect of vitamin A supplementation on adipose tissue $11 \beta$-HSD1 activity in WNIN/Ob lean and obese rats. Values are means \pm S.E for 8 rats. Mean values with * mark are significant at $\mathrm{P} \leq 0.05$ level (by one-way ANOVA). Comparisons were made between normal and high vitamin A-fed groups of each phenotype (Al-Lean: 2.6 mg vitamin A/kg diet, All-Lean: 129 mg vitamin $\mathrm{A} / \mathrm{kg}$ diet, Bl-Obese: $2.6 \mathrm{mg}$ vitamin $\mathrm{A} / \mathrm{kg}$ diet and Bll-Obese: $129 \mathrm{mg} / \mathrm{kg}$ diet).

Effect of vitamin A supplementation on C/EBP $\alpha, \operatorname{LXR} \alpha$ mRNA and protein levels in liver

To explain the possible mechanism involved in the vitamin-A mediated downregulation of $11 \beta-H S D 1$ in liver, we studied the hepatic expression of C/EBP $\alpha$ and LXR $\alpha$ both at mRNA and protein levels. Vitamin A supplementation significantly increased the hepatic $\mathrm{C} / \mathrm{EBP} \alpha$ gene expression in both the phenotypes (Figure 3) as compared with their respective control rats. However, elevated hepatic $\mathrm{C} / \mathrm{EBP} \alpha$ protein levels were observed only in vitamin A-supplemented lean rats, where as in obese rats, hepatic $\mathrm{C} / \mathrm{EBP} \alpha$ protein levels were significantly low (Figure 3). Hepatic LXR $\alpha$ mRNA and protein levels significantly decreased by feeding of vitamin A enriched diet to WNIN/Ob lean and obese rats as compared with their respective stock diet fed-lean and obese counterparts (Figure 4).

Effect of vitamin A supplementation on hepatic glycerol3-phospahte dehydrogenase (GPDH) activity

As vitamin A supplementation decreased hepatic $11 \beta$ HSD1 activity in lean and obese rats, we studied the activity of cytosolic glycerol-3-phosphate dehydrogenase (GPDH), which is induced by glucocorticoids in hepatocytes (17). In line with the decreased $11 \beta$-HSD1 activity, GPDH activity was also significantly decreased by vitamin A supplementation in both the phenotypes as compared with their respective controls (Figure 5).

\section{Discussion}

In this communication, we report the impact of chronic feeding of vitamin A-enriched diet on 11 $\beta$-HSD1 activity in liver and visceral fat of WNIN/Ob obese rats, a new genetic rat model of obesity. Here, we demonstrate that 
(A)

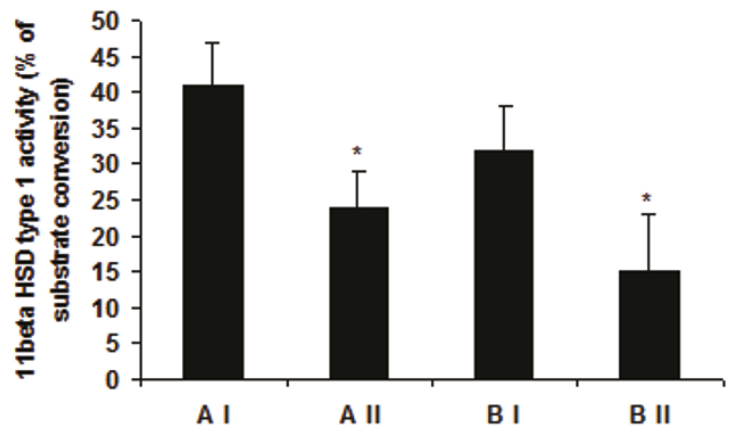

(c) $11 \beta$-HSD 1
(B)

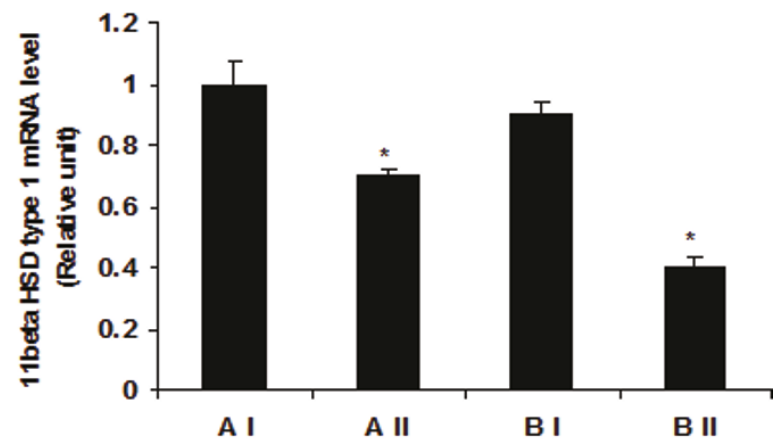
A I
A II
B I
B II

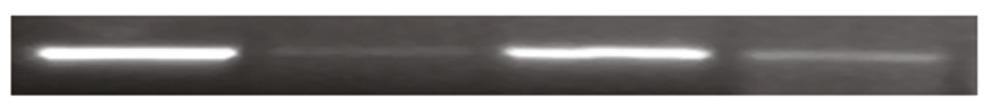

(D) $\beta$-Actin

Al

A II

B I

B II

Figure 2 (A) Effect of vitamin A supplementation on hepatic 11ß-HSD1 activity in WNIN/Ob lean and obese rats. Values are means \pm S.E for 8 rats. Mean values with * mark are significant at $P \leq 0.05$ level (by one-way ANOVA). (B) Effect of vitamin A supplementation on $11 \beta-H S D 1$ gene expression in liver of WNIN/Ob lean and obese rats. Quantified densitometric values are expressed relative of 1 for lean control rats (Al). (C) Representative photo of $11 \beta-H S D 1$ PCR product, stained by ethidium bromoide. (D) Representative photo of PCR $\beta$-Actin product (internal control), stained by ethidium bromide. Comparisons were made between normal and high vitamin A-fed groups of each phenotype (Al-Lean: $2.6 \mathrm{mg}$ vitamin A/kg diet, All-Lean: $129 \mathrm{mg}$ vitamin A/kg diet, Bl-Obese: $2.6 \mathrm{mg}$ vitamin A/kg diet and Bll-Obese: $129 \mathrm{mg} / \mathrm{kg}$ diet).

feeding of vitamin A-enriched diet to WNIN/Ob obese rats decreases body weight, fat mass and $11 \beta-$ HSD 1 activity in liver and visceral fat. To our knowledge, this is the first study to link vitamin A and pre-receptor metabolism of glucocorticoids in normal and obese conditions.

Retinoic acid, one of the metabolically-active forms of vitamin A, regulates cellular gene expression through retinoic acid receptors (RARs) and retinoid $\times$ receptors (RXRs). Adipose tissue is a good target organ for vitamin A action, as it stores significant amount of vitamin A and expresses RAR and RXR transcription factors. Retinoic acid is known to inhibit preadipocyte differentiation [18] and remodel white adipose tissue to brown adipose tissue [19]. Retinaldehyde, another functional form of vitamin $\mathrm{A}$ is reported to decrease adipogenesis and ameliorate diet-induced obesity in rodent models [20]. In line with our previous observation, high (but not toxic) dose of vitamin A decreased visceral fat mass and bodyweight in obese rats [10]. Previous studies have reported that cortisol (corticosterone in rodents) is essential for preadipocyte differentiation [21] and adipose-specific overexpression of $11 \beta$-HSD1 in mice, results in increased preadiocyte differentiation [3]. As reported previously, WNIN/Ob obese rats have exhibited higher $11 \beta$-HSD1 activity in visceral fat than their lean counter parts [22]. In the present study, vitamin A significantly decreased $11 \beta$-HSD1 activity in visceral fat, which is associated with significant decrease in visceral fat mass. Vitamin A mediated visceral fat loss in obese rats could be due to decreased preadipocyte differentiation, as reduced $11 \beta-$ HSD1 activity results in decreased tissue corticosterone levels. In contrast to the observation in obese rats, vitamin A-challenged lean rats had increased 11 $\beta$-HSD1 activity in visceral fat, however, increased enzyme activity had no impact on visceral fat mass. The differential effects of vitamin A on 11 $\beta$-HSD1 activity and visceral fat mass in lean and obese rats could be due to other physiological factors that are altered in obese condition. 


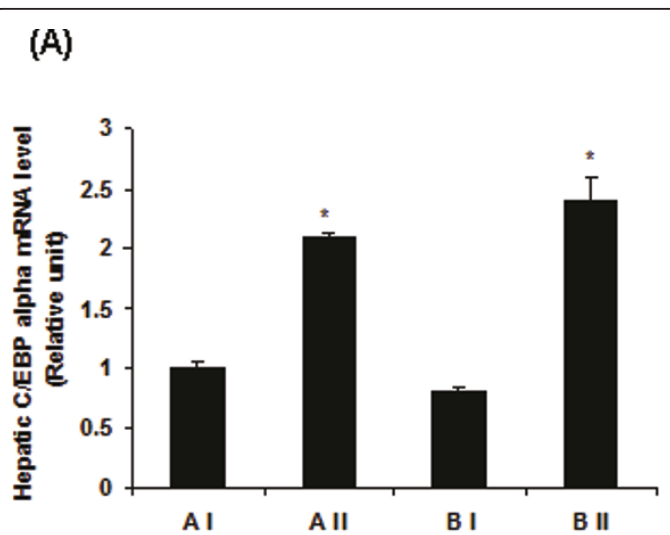

(B) CIEBP- $\alpha$

A I A II BI B II

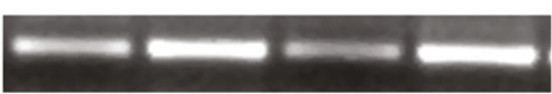

(c) $\beta$-Actin

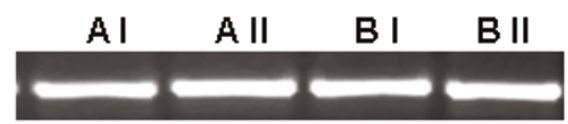

(D)

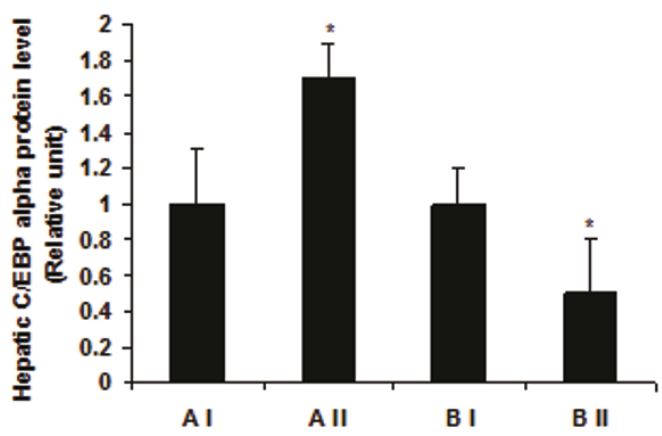

(E)

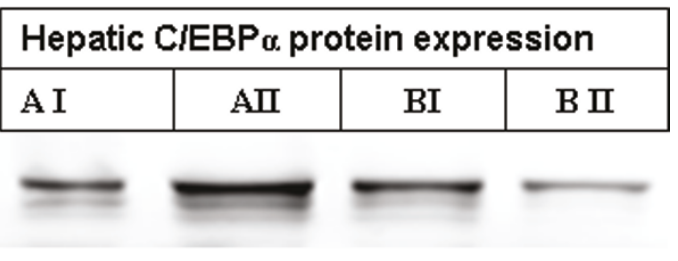

(F)

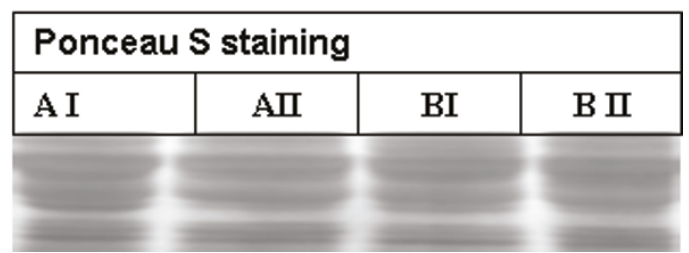

Figure 3 (A) Effect of vitamin A supplementation on hepatic C/EBP $\alpha$ mRNA and protein levels in WNIN/Ob lean and obese rats. Quantified densitometric values are expressed relative of 1 for lean control rats (AI). (B) Representative photo of C/EBP $\alpha$ PCR product, stained by ethidium bromoide. (C) Representative photo of $\beta$-Actin PCR product (internal control), stained by ethidium bromide. (D) Quantified densitometric values from the western blot are expressed relative of 1 for A-I (lean) as control. (E) Representative Western blot of hepatic C/EBP $\alpha$ protein. (F) Ponseau stained western blot. Values are means \pm SE for 3-4 rats at $\mathrm{P} \leq 0.05$ level. Comparisons were made between normal and high vitamin A-fed groups of each phenotype (Al-Lean: $2.6 \mathrm{mg}$ vitamin A/kg diet, All-Lean: $129 \mathrm{mg}$ vitamin A/kg diet, Bl-Obese: $2.6 \mathrm{mg}$ vitamin A/kg diet and Bll-Obese: $129 \mathrm{mg} / \mathrm{kg}$ diet).

Vitamin A may regulate the $11 \beta-\mathrm{HSD} 1$ activity, by altering its gene expression through direct and indirect mechanisms. Presently, retinoic acid-response elements are not reported on $11 \beta-\mathrm{HSD} 1$ promoter to support the direct effect of vitamin A on 11 $\beta$-HSD1 gene expression. $\mathrm{C} / \mathrm{EBP} \alpha$ has been shown to be obligatory for the expression of $11 \beta-H S D 1$ [4]. Previous studies have reported that retinoic acid downregulates the expression of genes like resistin that are regulated by $\mathrm{C} / \mathrm{EBP} \alpha$ in adipose tissue [13]. Vitamin A-mediated regulation of 11 $\beta$-HSD1 gene expression in adipose tissue may be mediated by indirect mechanism through $\mathrm{C} / \mathrm{EBP} \alpha$.

$11 \beta$-HSD1 plays an important role in the regulation of carbohydrate and lipid metabolism in liver. 11 $\beta$-HSD1$\mathrm{KO}$ mice have improved insulin sensitivity [4], where as transgenic overexpression of $11 \beta-\mathrm{HSD} 1$ in liver results in the development of impaired glucose tolerance [23]. WNIN/Ob obese rats have lower hepatic $11 \beta-$ HSD 1 expression and activity as observed in other obese rodent models [22]. In the present study, vitamin A supplementation at high doses decreased hepatic $11 \beta-H S D 1$ activity and expression in both lean and obese phenotypes. Supporting to our hypothesis, activity of GPDH, a glucocorticoid inducible enzyme, was also decreased in vitamin A supplemented lean and obese rats. Based on these observations, it is possible that vitamin A may regulate the expression of hepatic glucocorticoid target genes by regulating the expression of $11 \beta-H S D 1$.

To understand the possible mechanisms involved in the downregulation of $11 \beta$-HSD1 in liver, we studied the expression of $\mathrm{C} / \mathrm{EBP} \alpha$ at mRNA and protein levels. In our study, vitamin A supplementation increased 


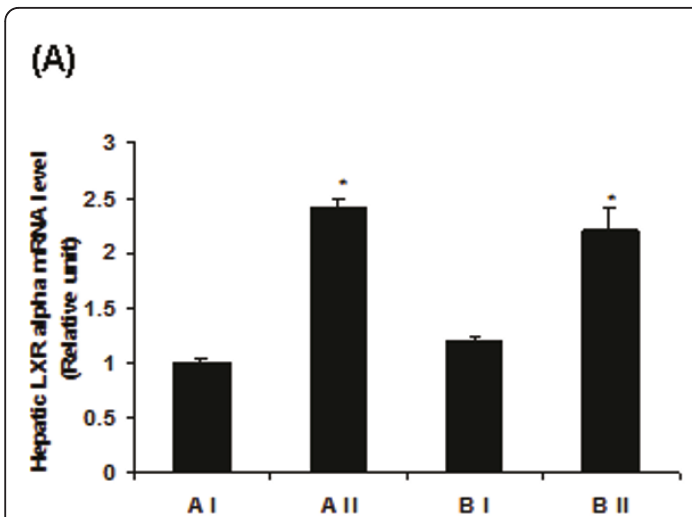

(B) LXR- $\alpha$

\section{A I}

A II

B I

B II

(C) B-Actin

Al

A II

B I

B II

(D)

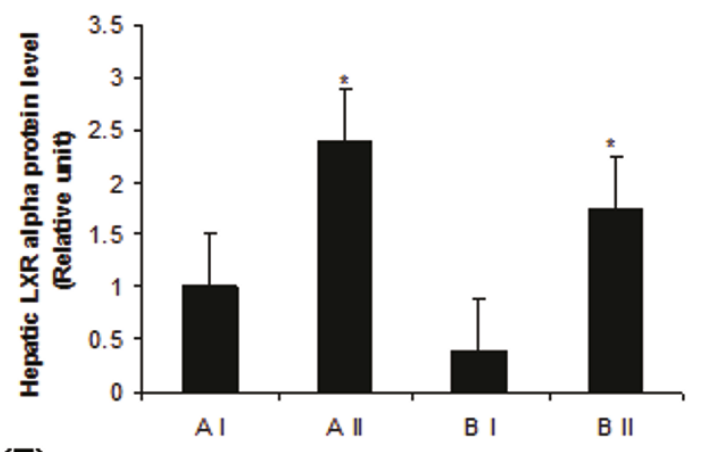

(E)

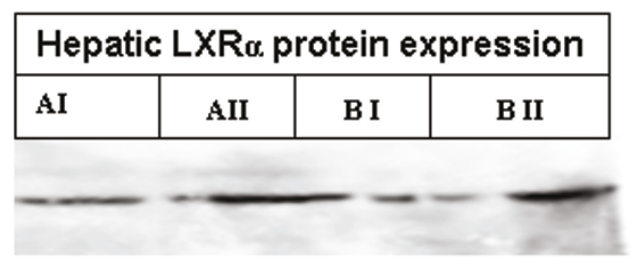

(F)

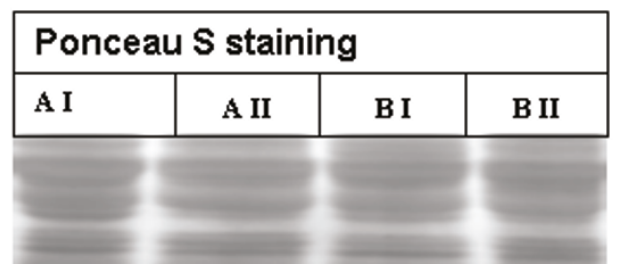

Figure 4 (A) Effect of vitamin A supplementation on hepatic LXR $\alpha$ mRNA and protein levels in WNIN/Ob lean and obese rats. Quantified densitometric values are expressed relative of 1 for Al (lean) as control. (B) Representative photo of LXRo PCR product, stained by ethidium bromoide. (C) Representative photo of $\beta$-Actin PCR product (internal control), stained by ethidium bromide. (D) Quantified densitometric values from the western blot are expressed relative of 1 for lean control rats (AI). (E) Representative Western blot of hepatic LXR $\alpha$ protein. (F) Ponseau stained western blot. Values are means \pm SE for 3-4 rats at $\mathrm{P} \leq 0.05$ level. Comparisons were made between normal and high vitamin A-fed groups of each phenotype (A I-Lean: $2.6 \mathrm{mg}$ vitamin A/kg diet, A II-Lean: $129 \mathrm{mg}$ vitamin A/kg diet, B I-Obese: $2.6 \mathrm{mg}$ vitamin A/kg diet and B Il-Obese: $129 \mathrm{mg} / \mathrm{g}$ diet).

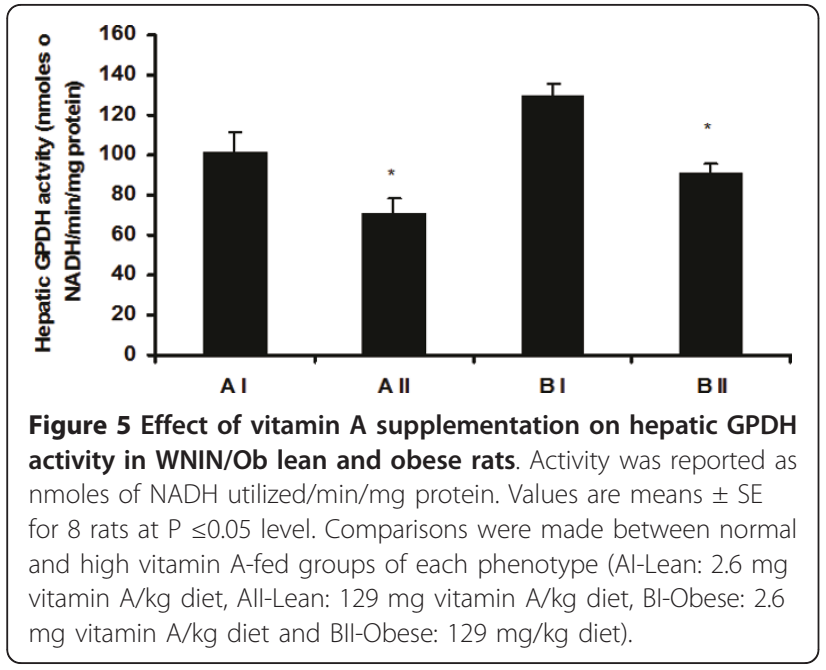

hepatic $\mathrm{C} / \mathrm{EBP} \alpha$ gene expression in vitamin A-treated lean and obese rats. In contrast to increased mRNA levels, C/EBP $\alpha$ protein levels decreased in vitamin Asupplemented obese rats, suggesting the role of posttranscriptional regulatory mechanisms. Possibly, vitamin A-mediated downregulation of hepatic $11 \beta$-HSD1 is mediated through different mechanisms in lean and obese rats, in other words, vitamin A-mediated down regulation of hepatic $11 \beta-H S D 1$ may be C/EBP $\alpha$-dependent in obese rats, while it is independent of $\mathrm{C} / \mathrm{EBP} \alpha$ in lean rats.

Previous studies have reported that LXR $\alpha$ ligands down regulate $11 \beta-\mathrm{HSD} 1$ through indirect mechanisms [7]. In this study, vitamin A supplementation increased hepatic LXR $\alpha$ mRNA and protein levels in WNIN/Ob lean and obese rats. In support to the elevated LXR $\alpha$ 
gene expression, ABCA1 (ATP-binding cassette transporter protein 1), a classical target gene of LXR $\alpha$ is elevated in lean and obese rats (unpublished data). Vitamin A-mediated downregulation of hepatic $11 \beta-H S D 1$ gene expression is may be mediated through LXR $\alpha$. Another mechanism, through which dietary vitamin A may down regulate $11 \beta-\mathrm{HSD} 1$, is by providing high concentration of RXR ligand, 9-cis-retinoic acid. LXR $\alpha$ forms heterodimer with RXR and this step is essential for LXR $\alpha$ mediated gene transcription. Higher concentration of RXR ligand may result in the increased recruitment of LXR $\alpha:$ RXR heterodimers to $11 \beta-$ HSD 1 gene promoter resulting in decreased $11 \beta-$ HSD1 gene expression.

$11 \beta$-HSD1 gene expression in liver and adipose tissue is also regulated by various hormones and cytokines present in the plasma [24]. It is possible that Vitamin A-mediated alterations in the levels of these signaling molecules may also affect the $11 \beta-\mathrm{HSD} 1$ activity in liver and adipose tissue of WNIN/Ob lean and obese rats.

\section{Conclusions}

In summary, we showed for the first time that supraphysiological dose of vitamin A through diet decreases $11 \beta$-HSD1 activity in visceral fat and liver of WNIN/Ob obese rat. The observed vitamin A-mediated reduction in $11 \beta$-HSD 1 activity in the visceral fat of obese rats may contribute to the decreased visceral fat mass in this model. Further research is needed to understand the mechanisms involved in the regulation of $11 \beta-H S D 1$ by various nutrients in tissues like liver and visceral fat in order to develop appropriate dietary interventions to prevent the development of obesity and insulin resistance.

\section{List of abbreviations used}

11ß-HSD1: 11ß-hydroxysteroid dehydrogenase type 1; C/EBPa: CCAAT/ Enhancer-binding protein $a_{\text {; }}$ LXRa: Liver $\times$ receptor $a$; RXR: Retinoid $\times$ receptor; RAR: Retinoic acid receptor; HPLC: High-performance liquid chromatography; SDS-PAGE: Sodium dodecyl sulphate- polyacrylamide gel electrophoresis.

\section{Acknowledgements}

We are grateful to Dr.B.Sesikeran, Director, of the Institute for constant encouragement during the conduct of the study. Mr.S.S.S.V.Prasad thanks the Council for Scientific and Industrial Research (CSIR), India for the award of a research fellowship to carryout this work.

\footnotetext{
Author details

'Department of Biochemistry, National Institute of Nutrition, Indian Council of Medical Research, Jamai Osmania PO, Hyderabad-500 604, Andhra Pradesh, India. ${ }^{2}$ National Center for Laboratory Animal Sciences, Indian Council of Medical Research, Jamai Osmania PO, Hyderabad-500 604, Andhra Pradesh, India.
}

\section{Authors' contributions}

SSSVP carried out plasma corticosterone and 11ß-HSD1 assays, gene expression work, data analysis and prepared the first draft. PA carried out the animal experiment, immunoblotting work, estimated retinol, GPDH activity, data analysis and manuscript editing. GNV was responsible for breeding and supply of animals. VA hypothesized, designed and supervised the experiment. VA reviewed, finalized the draft and also gave permission to submit manuscript. All authors read and approved the content of the manuscript.

\section{Competing interests}

The authors declare that they have no competing interests.

Received: 2 August 2010 Accepted: 23 June 2011

Published: 23 June 2011

\section{References}

1. Livingstone DEW, Jones G, Smith K, Jamieson PM, Andrew R Kenyon CJ, Walker BR: Understanding the role of glucocorticoids in obesity: tissuespecific alterations of corticosterone metabolism in obese zucker rats. Endocrinology 2000, 141:560-563.

2. Rask E, Olsson $T$, Soderberg $\mathrm{S}$, Andrew $R$, Livingstone DE, Johnson $\mathrm{O}$, Walker BR: Tissue-specific dysregulation of cortisol metabolism in human obesity. J Clin Endocrinol Metab 2001, 86:1418-1421.

3. Masuzaki H, Paterson J, Shinyama H, Morton NM, Mullins JJ, Seckl JR, Flier JS: A transgenic model of visceral obesity and the metabolic syndrome. Science 2001, 294:2166-2170.

4. Morton N, Paterson J, Masuzaki H, Holmes MC, staels B, Fieevet C, Walker B, Flier J, Mullins J, Seckl : Reduced 11ß-Hydroxystweroid dehydrogenase type 1-mediated intra-adipose glucocorticoid regeneration: a novel protective adaptation to and treatment for the metabolic syndrome. Program\& Abstracts of the 85th Annual Meeting of the Endocrine Society 2003, 114, June 19-22, abstract OR39-5.

5. Nuotio-Antar Alli M, Hachey David L, Hasty Alyssa H: Carbenoxolone treatment attenuates symptoms of metabolic syndrome and atherogenesis in obese, hyperlipidemic mice. Am J Physiol Endocrinol Metab 2007, 293:E1517-E1528.

6. Williams LJ, Lyons V, MaLeod I, Rajan V, Darlington GJ, Poli V, Seckl JR, Chapman KE: C/EBP regulates hepatic transcription of $11 \beta-$ Hydroxystweroid dehydrogenase type 1. A novel mechanism for crosstalk between the C/EBP and glucocorticoid signaling pathways. J Biol Chem 2000, 275:30232-30239.

7. Stuling TM, Oppermann U, Steffensen KR, Schuster GU, Gustafsson JA: Liver $\times$ receptors down regulate $11 \beta$-Hydroxystweroid dehydrogenase type 1 expression and activity. Diabetes 2002, 51:2426-2433.

8. Giridharan NV, Harishankar N, Satyavani M: A new rat model for the study of obesity. Scand J Lab Anim Sci 1996, 23:131-137.

9. Kumar Monica V, Sunvold Gregory D, Scarpace Philip J: Dietary vitamin A supplementation in rats: suppression of leptin and induction of UCP1 mRNA. J Lip Res 1999, 40:824-29.

10. Jeyakumar SM, Vajreswari A, Giridharan NV: Chronic dietary vitamin A supplementation regulates obesity in an obese mutant WNIN/Ob rat model. Obesity 2006, 14:52-59.

11. Jeyakumar SM, Vajreswari A, Giridharan NV: Vitamin A supplementation induces adipose tissue loss through apoptosis in lean and but not in obese rats of WNIN/Ob strain. J Mol Endocrinol 2005, 35:391-398.

12. Felipie Francisco, Luisa Bonet M, Ribot Joan, Palou Andreu: Modulation of Resistin Activity by Retinoic Acid and vitamin A status. Diabetes 2004, 53:882-89.

13. White $\mathrm{H}$, Kaplan N: Purification and properties of two types of nucleotide linked glycerol-3-phosphate dehydrogenase from chicken breast muscle and chicken liver. J Biol Chem 1969, 244:6031-6039.

14. Chomczyski P, Sacchi N: Single step method of RNA isolation by acid guanidinium thiocyanate phenol chloroform extraction. Anal Biochem 1987, 162:156-9.

15. Qiao L, Maclean PS, Schaack J, Orlicky DJ, Darimont C, Pagliassotti M, Friedman JE, Shao J: C/EBPa regulates human adiponectin gene transcription through an intronic enhancer. Diabetes 2005, 54:1744-1754

16. Shao J, Qiao L, Janssen RC, Pagliassotti M, Friedman JE: Chronic hyperglycemia enhances PEPCK gene expression and hepatocellular glucose production via elevated liver activating protein/liver inhibitory protein ratio. Diabetes 2005, 54:976-984

17. Mayer Robert D, Preston Sheryl L, McMorris F Arthur: Glycerol-3-phosphate dehydrogenase is induced by glucocorticoids in hepatocytes and hepatoma cells in vitro. J Cell Physiol 2005, 114(2):203-208. 
18. Schwarz EJ, Reginato MJ, Shao D, Krakow SL, Lazar MA: Retinoic acid blocks adipogenesis by inhibiting C/EBPbeta-mediated transcription. Mol Cell Biol 1997, 17:1552-61.

19. Mercader Josep, Ribot Joan, Murano Incoronata, Felipe Francisco, Cinti Saverio, Bonet Luisa M, Palou Andreu: Remodeling of White Adipose Tissue after Retinoic Acid Administration in Mice. Endocrinology 2006, 147:5325-32.

20. Ziouzenkova Ouliana, Orasanu Gabriela, Sharlach Molly, Akiyama Taro E, Berger Joel P, Viereck Jason, Hamilton James A, Tang Guangwen, Dolnikowski Gregory G, Vogel Silke, Duester Gregg, Plutzky Jorge: Retinaldehyde represses adipogenesis and diet-induced obesity. Nat Med 2007, 13:95-702.

21. Hauner H, Schmid P, Pfeiffer EF: Glucocorticoids and insulin promote the differentiation of human adipocyte precursor cells in to fat cells. $J$ Clin Endocrinol Metab 1987, 64:832-835.

22. vara prasad Sakamuri SS, Prashanth Anamthathmakula, Kumar Pavan Chodavarapu, Reddy Sirisha J, Giridhara Nappan V, Vajreswari Ayyalasomayajula: A novel-genetically-obese rat model with elevated $11 \beta$-hydroxysteroid dehydrogenase type 1 activity in subcutaneous adipose tissue. Lipids in Health Dis 2010, 9:132.

23. Paterson Janice M, Morton Nicholas M, Fievet Catherine, Kenyon Christopher J, Holmes Megan C, Staels Bart, Seckl Jonathan R, Mullins John J: Metabolic syndrome without obesity: Hepatic overexpression of $11 \beta$-Hydroxystweroid dehydrogenase type 1 in transgenic mice. Proc Natl Acad Sci 2004, 101:7088-7093.

24. Tomlinson Jeremy W, Walker Elizabeth A, Bujalska Iwona J, Draper Nicole, Lavery Gareth G, Cooper Mark S, Hewison Martin, Stewart Paul M: 11 $\beta$ Hydroxysteroid Dehydrogenase Type 1: A Tissue-Specific Regulator of Glucocortcoid Response. Endocrinology 2004, 25:831-866.

doi:10.1186/1475-2891-10-70

Cite this article as: Sakamuri et al:: Vitamin A decreases pre-receptor amplification of glucocorticoids in obesity: study on the effect of vitamin $A$ on 11 beta-hydroxysteroid dehydrogenase type 1 activity in liver and visceral fat of WNIN/Ob obese rats. Nutrition Journal 2011 10:70.

\section{Submit your next manuscript to BioMed Central} and take full advantage of:

- Convenient online submission

- Thorough peer review

- No space constraints or color figure charges

- Immediate publication on acceptance

- Inclusion in PubMed, CAS, Scopus and Google Scholar

- Research which is freely available for redistribution

Submit your manuscript at www.biomedcentral.com/submit
Biomed Central 